Volume: 11

Issue: 03

Years: 2021
Research Article

\section{Brain Gym Therapy For Schizophrenics Cognitive Function In Mental Hospita}

\author{
N M Sumartyawati ${ }^{1}$, N L Sudiarti ${ }^{2}$, I M E

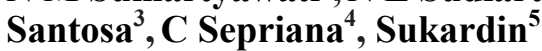 \\ ${ }^{1}$ Rumah Sakit Jiwa Mutiara Sukma Propinsi NTB, Jl. Ahmad Yani \\ No. 1 Selagalas, Kecamatan Sandubaya, Mataram-NTB \\ ${ }^{2-5}$ Sekolah Tinggi Ilmu Kesehatan Mataram, \\ Jl. Swakarsa III No. 10-14 kekalik Mataram-NTB \\ Email Corespondent : langitku240615@gmail.com
}

\section{open 2 access}

Editor: KS

Received: 25/06/2021

Accepted: 08/09/2021

Published: 27/09/2021

Available Article :

10.33221/jiiki.v11i03.1239

Copyright: (C2021 This article has open access and is distributable under the terms of the Creative Commons Attribution License, which permits unrestricted use, distribution, and reproduction in any medium, provided the name of the author and the original source are included. This work is licensed under a Creative Commons Attribution-Share Alike $\mathbf{4 . 0}$ International License

Conflict of interest statement: The author has no conflict of interest to declare

Funding: This study did not receive any grant from funding agencies

\begin{abstract}
Background: Schizophrenia is still often a problem in individuals that can cause cognitive dysfunction throughout their lives. With brain exercise therapy, it is hoped that can improve cognitive function in schizophrenia.

Objectives: This study aims to determine the effect of brain exercise therapy on cognitive function in schizophrenic patients.

Methods: A quasy experimental study with a non-equivalent control group before and after the design was performed. The population was all schizophrenic patients in the intermediate room. Incidental sampling was carried out and obtained 40 cooperative schizophrenic patients and its divided into treatment and control groups. This study describes the validity and reliability of a new interview-based assessment of cognition, the Schizophrenia Cognition Rating Scale (SCoRS), that involves interviews with patients and informants. The difference in effect was measured using the independent t-test with SPSS

Results: Soft cognitive function in patients before brain exercise therapy in the treatment group was $9(45 \%)$, moderate cognitive function in patients before brain exercise therapy in the control group was $13(65 \%)$, soft cognitive function in patients after being given brain exercise therapy in the treatment group was $14(70 \%)$, moderate cognitive function in patients after brain exercise therapy was given to the control group, namely $14(70 \%)$. The statistic test obtained P-Value $=0,001<\alpha(0,05)$.

Conclusion: The study showed that there were different effects of brain exercise therapy on the reduction of cognitive function in schizophrenia patients in the intermediate room.
\end{abstract}

Keywords: brain gym therapy, cognitive function, schizophrenia.

\title{
Introduction
}

Schizophrenia is a mental disorder / chronic brain disorder that affects individuals throughout their life which is characterized by decreased communication skills, reality disorders (hallucinations and delusions), abnormal effect, cognitive impairment (unable to think abstractly), and having difficulty carrying out daily activities. ${ }^{1}$ WHO (2016) said that there are 21 million people affected by schizophrenia in the world. ${ }^{2}$ In Indonesia, the proportion of schizophrenia mental disorders increased by $5.3 \%$ of cases from 2013 to 2018, and West Nusa Tenggara is a province in the 3rd position in terms of the prevalence of households with schizophrenia mental disorders, namely $10 \%{ }^{3}$

Clients with mental disorders often see setbacks marked by loss of motivation and responsibility, apathy, avoidance of activities, and social relationships. Basic abilities are often compromised, such as 
Activities Of Daily Living (ADL). ${ }^{4}$ Research conducted by Trihardani regarding self-care which consists of eating, bathing, toileting, and personal hygiene schizophrenic patients at the hospital showed that $38 \%$ of people with schizophrenia are in the category of dependence mild, $28 \%$ in the category of dependence medium, $13 \%$ are in the category of high dependency, $13 \%$ are in the total dependency category, and 3\% are in the independent category. ${ }^{4}$ Research conducted by Barton shows that $50 \%$ of sufferers. Chronic schizophrenia who undergo a rehabilitation program can return to productivity and be able to readjust into the family and society. ${ }^{5}$ The increase in the number of cases of schizophrenia will have an impact on increasing the burden on the state and decreasing human productivity in the long term. ${ }^{2}$ Schizophrenic patients with symptoms of cognitive deficits are associated with information processing problems that include aspects of memory, attention, communication, and difficulty in decision making. So that in everyday life, cognitive abilities are very important. ${ }^{1}$ Certain interventions in the health sector are needed to support the improvement of a person's cognitive function, especially in patients with mental disorders. ${ }^{6}$

Management of schizophrenia currently still focuses on controlling symptoms and tends to ignore cognitive aspects. ${ }^{7}$ When compared to psychotic symptoms, cognitive deficits can better predict the ability of social functioning in schizophrenics. ${ }^{7}$ The administration of antipsychotic drugs can reduce psychotic symptoms in the majority of schizophrenics but does little to help restore social function. ${ }^{8}$ One form of cognitive rehabilitation is through a rehabilitation program. ${ }^{5}$ Rehabilitation in schizophrenic patients is an effort to improve the patient's ability to live independently in the community. ${ }^{4}$ The rehabilitation program includes study skills, work skills, and joint sports. The importance of exercise and physical activity is to develop or enhance the process of good coordination and fitness. Exercise as a form of exercise can benefit and affect general health and happiness. Exercise can also provide positive energy and can increase attitude and motivation. ${ }^{4}$ Exercise therapy is also a form of non-pharmacological management with the aim of maintaining the function of the body's organs. ${ }^{9}$

One form of exercise that can help improve cognitive function is brain exercise therapy. ${ }^{10}$ Brain exercise is defined as a series of simple movement exercises that can improve concentration, increase self-confidence, strengthen learning motivation, and are better able to control stress. This exercise promotes the balance of activities of the two hemispheres of the brain simultaneously, improves blood flow and oxygen to the brain, and improves the ability of brain structure and function to continue to develop due to stimulation. ${ }^{18}$ Brain exercise movements provide stimulation or stimulation to the two hemispheres of the brain that are physiologically coordinated through the corpus callosum, so that they can improve memory and other cognitive functions. ${ }^{18}$

Mutiara Sukma Mental Hospital is currently running a mental rehabilitation program that focuses on the rehabilitation room. Activities in the form of exercises such as gymnastics are still rarely carried out, especially in intermediate rooms. The purpose of this study was to determine the effect of brain exercise therapy on cognitive function of schizophrenia patients at Mutiara Sukma Mental Hospital.

\section{Methods}

This research is a quasi-experiment with a nonequivalent control group before-after design. The subjects in this study were schizophrenic patients in the room intermediate of RSJ Mutiara Sukma, NTB Province. The study population was all 65 schizophrenic patients in the intermediate room. Determination of the sample using incidental sampling and obtained 40 cooperative schizophrenia patients to be divided into treatment and control groups. This study describes the validity and reliability of a new interview-based assessment of cognition, the Schizophrenia Cognition Rating Scale (SCoRS), that involves interviews with patients and informants.

The group was given brain exercise therapy for seven consecutive days within 20-40 minutes, with 15 kinds of brain exercise movements in the morning. Both the treatment and control groups were given a pre-test and post-test. The data collected were then seen the difference in their effect on cognitive function using the Independent $t$-test with the help of SPSS 21 software.

\section{Result}


Tabel 1. Frequency Distribution Patient Cognitive Function Before Brain Exercise Therapy

\begin{tabular}{lllll}
\hline Cognitive Function & Treatment & \multicolumn{3}{c}{ Control } \\
\cline { 2 - 5 } & $\mathbf{N}$ & $\mathbf{\%}$ & $\mathbf{N}$ & $\mathbf{\%}$ \\
\hline Nil & 0 & 0 & 0 & 0 \\
Mild & 9 & 45 & 3 & 15 \\
Moderate & 6 & 30 & 13 & 65 \\
Heavy & 5 & 25 & 4 & 20 \\
\hline Total (n) & 20 & 100 & 20 & 100 \\
Mean & 44 & & 50 & \\
SD & 14,4 & & 10,5 & \\
\hline
\end{tabular}

Based on table 1 the results of this study indicate that soft cognitive function in patients before brain exercise therapy in the treatment group was $9(45 \%)$, moderate cognitive function in patients before brain exercise therapy in the control group was 13 (65\%).

Table 2. Frequency Distribution Cognitive Function of Schizophrenic Patients After Being Given Brain Exercise Therapy

\begin{tabular}{lcccc}
\hline Cognitive Function & Treatment & Control \\
\cline { 2 - 5 } & $\mathbf{N}$ & $\mathbf{\%}$ & $\mathbf{N}$ & $\mathbf{\%}$ \\
\hline Nil & 0 & 0 & 0 & 0 \\
Mild & 14 & 70 & 4 & 20 \\
Moderate & 4 & 20 & 14 & 70 \\
Heavy & 2 & 10 & 2 & 20 \\
\hline Total (n) & 20 & 100 & 20 & 100 \\
Mean & 36 & & 47 & \\
SD & 11,9 & & 8,4 & \\
\hline
\end{tabular}

Based on table 2 the results of this study indicate that soft cognitive function in patients after being given brain exercise therapy in the treatment group was $14(70 \%)$, moderate cognitive function in patients after brain exercise therapy was given to the control group, namely $14(70 \%)$.

Table 3 The results of the analysis of the effect of brain exercise therapy using the independent $t$-test

\begin{tabular}{lccc}
\hline Variable & Difference Mean & $\alpha$ & P Value \\
\cline { 2 - 2 } $\begin{array}{l}\text { Brain Exercise Therapy Group } \\
\text { Control Group }\end{array}$ & 2,775 & 0,05 & 0,001 \\
\hline
\end{tabular}

Based on table 3 the results of this study indicate that there are differences in the effect of brain exercise therapy on cognitive function decline in schizophrenic patients in the intermedia room, the $\mathrm{P}$-Value is 0,001 .

\section{Discussion}

\section{Frequency Distribution Cognitive Function Of Schizophrenic Patients Before Brain Exercise Therapy}

The results of the analysis based on the frequency distribution of the cognitive function of schizophrenia patients before brain therapy exercise showed that more in the cognitive function treatment group of patients before brain exercise therapy categories of soft cognitive function $9(45 \%)$, moderate cognitive function $6(30 \%)$, severe cognitive function $5(25 \%)$. Meanwhile, in the control group, the cognitive function of patients before brain exercise was in the category of moderate cognitive function $13(65 \%)$, severe cognitive function 4 (20\%), and soft cognitive function $3(15 \%)$. This study is in line with previous studies showing that cognitive function prior to brain exercise was in the category of moderate cognitive impairment as many as $4(66.7 \%)$, severe cognitive impairment as many as $2(33.3 \%)$. This study is in line with previous studies showing that cognitive decline in the elderly before brain exercise was done by 9 people $(50 \%)$ in the heavy category, and after doing brain exercise, there was an increase in the normal category. ${ }^{18}$ 
This is in accordance with the previous theory that schizophrenia patients who show a marked decline in cognition, affect, and behavior, schizophrenia is characterized by disturbances in thinking and in expressing thoughts through coherent and meaningful speech. Disturbances in thinking can be found both in the content and in the form of thoughts. ${ }^{11}$ Cognitive is the activity of the mind in which to know something, by thinking and understanding. ${ }^{12}$ The decline in cognitive abilities mainly appears in the form of decreased ability to execute (do something) and a decrease in the speed of processing something. This decrease causes difficulty in a person's social function, which includes the ability to care for oneself to live independently and in family roles, social interactions, and difficulties in getting a job. ${ }^{13,14}$ This cognitive problem includes problems in all aspects of memory, attention, form, and content of speech, decision making, and thought content. ${ }^{13}$ Cognitive Disorders include disturbances in thought or memory that describe a marked change from the actual level of individual functioning. ${ }^{11}$

From the results of research conducted by researchers and the results of related studies, it can be concluded that cognitive function has an important role in providing rehabilitation and reducing complaints in schizophrenic patients who experience impaired functions of daily life. With the practical approach given to schizophrenic patients, it can be done in various ways, one of which is brain exercise therapy. Brain gym therapy is able to improve attention, concentration, problem-solving skills, and the development of other aspects so that the possibility of increasing social, independent, and vocational skills will be better so that it will be able to provide a better level of integration. This brain exercise therapy will also activate two parts of the brain and combine the functions of all parts of the brain to improve cognitive abilities.

\section{Frequency Distribution Cognitive Function Of Schizophrenic Patients After Brain Exercise Therapy}

The results of the analysis based on the frequency distribution of cognitive function in schizophrenic patients after being given brain exercise therapy in the treatment group found that soft cognitive function was $14(70 \%)$, moderate cognitive function was $(20 \%)$, and severe cognitive function was $2(10 \%)$. While the results of the analysis after being given brain exercise therapy in the treatment group found that moderate cognitive function was $14(70 \%)$, soft cognitive function was 4 $(20 \%)$, and severe cognitive function was $2(20 \%)$. This study is in line with previous studies showing that cognitive function after brain exercise was found that moderate cognitive function was $4(66.7 \%)$, and severe cognitive function was $2(33.3 \%)$.

From the data, it is known that brain exercise can make a positive contribution to cognitive function in schizophrenia patients. Light exercise movements carried out in brain exercises, such as through hand and foot exercises, can provide stimulation or stimulus to the brain so that it can improve cognitive abilities. ${ }^{10}$ In this study, respondents were taught simple brain exercise movements, which can stimulate the brain to improve the patient's cognitive abilities. Another study supports that after brain exercise in the elderly for 3 weeks every day the cognitive function of the elderly has increased in terms of recognizing place, time, counting numbers, remembering, and paying attention. ${ }^{18}$

This is in accordance with the previous theory which states that functional brain maintenance can be done by various learning processes, including learning to move, learning to remember, learning to feel, and so on. All these learning processes will always stimulate the brain centers (brain learning stimulation), in which there are centers that take care of various body functions. Brain exercise is defined as a series of simple movement exercises that can improve concentration, increase selfconfidence, strengthen learning motivation, and are better able to control stress. This exercise promotes the balance of activities of the two hemispheres of the brain simultaneously, improves blood flow and oxygen to the brain, and improves the ability of brain structure and function to continue to develop due to stimulation. ${ }^{18}$ Brain exercise movements provide stimulation or stimulation to the two hemispheres of the brain that are physiologically coordinated through the corpus colostrum so that they can improve memory and other cognitive functions. ${ }^{18}$

From the results of research conducted by researchers and the results of related research, it can be concluded that it is recommended that brain exercise can be done regularly with various learning processes such as learning to move, learning to remember, learning to feel. Therefore, brain exercise has an important benefit, namely, it can improve cognitive function in schizophrenic patients when compared to before being given brain exercise. Through the movement of the game if the hands and feet can produce a stimulus that can improve cognitive function. 


\section{Analysis Of The Effect Of Brain Exercise Therapy On Cognitive Function In Schizophrenia Patients}

The results of the analysis obtained from statistical tests that the P-Value of 0.001 means that there are differences in the decline in cognitive impairment in schizophrenic patients after being given brain exercise therapy. This study is in line with previous studies. The results of this study indicate that the P-Value is 0.014 , which means that there is an effect of brain exercise on cognitive function. This study is in line with previous studies that shows there is a significant effect of giving brain exercise on cognitive function with P-Value 0.000 .

This is also in accordance with the previous theory that brain gym is an attempt to generate neuron functions in coordinating body movements. ${ }^{19}$ The more often we do brain exercise, the more neuron connections in our brain. Therefore training does not depend on the training approach model and training duration, but rather on the intensity of the exercise. ${ }^{15}$ Brain exercise can increase brain activity through simple movements designed to activate all parts of the brain. This process will always stimulate the brain learning stimulation, in which there are centers that take care of various body functions. ${ }^{20,21}$ Brain exercise activates all parts of the brain for academic ability, behavioral relationships, and attitudes because the brain is divided into two hemispheres, namely the right brain and the left brain. Each part has a different function. The left brain is associated with potential in language skills (verbal), object construction (technical and mechanical), temporal, logical, analytical, rational, and structured concept of activity. While the right brain has potential in creative abilities (ability to take initiative and generate ideas), visual abilities, intuitive potential, abstract, and emotional (related to taste values). ${ }^{20}$ Movement in brain exercise has various benefits, namely improving blood flow, increasing oxygen intake to the brain, and maximizing the function of the right and left brain. ${ }^{10}$ Where the brain needs a supply of blood, oxygen, and energy for maintenance so that it can work optimally. In this case, it certainly supports the improvement of one's cognitive function.

From the results of research conducted by researchers and related research results, it can be concluded that if we do physical activities that can directly stimulate the brain and are carried out regularly, it can increase a protein in the brain called Brain-Derived Neurotrophic Factor (BDNF). This BDBF protein plays an important role in keeping nerve cells fit and healthy. This BDBF has an important role in memory function. This BDBF can be stimulated by doing sports activities so that it has benefits for improving cognitive function.

\section{Conclusion}

On the results of research on brain exercise therapy for cognitive function of schizophrenia in mental hospital. So it can be formulated into several conclusions, namely, there are differences in the effect of brain exercise therapy on cognitive function decline in schizophrenic patients in the intermedia room.

\section{Conflict of Interest Declaration}

Declare that this research is independent of the conflict of interest of both individuals and organizations

\section{Acknowledge}

Thank you to all participant in this study

\section{Funding}

This study is personal funding

\section{References}

1. Sovitriana R., Psi MS. Dinamika Psikologis Kasus Penderita Skizofrenia. Uwais Inspirasi Indonesia.; 2019.

2. Kementerian Kesehatan Republik Indonesia. Peran Keluarga Dukung Kesehatan Jiwa Masyarakat. Kemenkes. 2016.

3. Riset Kesehatan Dasar (Riskesdas). Badan Penelitian dan Pengembangan Kesehatan Kementerian RI. 2018.

4. Maryatun S. Peningkatankemandirian Perawatan Diri Pasien Skizofrenia Melalui Rehabilitasi Terapi Gerak. Jurnal Keperawatan Sriwijaya.; 2015.

5. Hawari D. Skizofrenia Pendekatan Holistik pada Gangguan Jiwa. Ed.3 ed. Jakarta: FKUI.; 2012.

6. Yudhantara DS., Istiqomah, R. Sinopsis Skizofrenia untuk Mahasiswa Kedokteran. Malang: UB Press.; 2018. 
7. Richard S. E., Keefe WSF. How should DSM-Vcriteria for Schizophrenia Include Cognitive Impairment. Schizophrenia Bulletin ; 33: 912-20.; 2007.

8. Michael F., Green, PDH. Cognition in Schizophrenia: Past, Present, and Future. Schizophrenia Research: Cognition. 2014;1:e1-e9.; 2014.

9. Sumartyawati NM. Pengaruh Senam Ergonomis terhadap Penurunan Skala Nyeri pada Lansia dengan Osteoartritis di Pstw Puspakarma. PrimA: Jurnal Ilmiah Ilmu Kesehatan. 2017;1.; 2017.

10. Muhammad A., Dahsyatnya. Senam Otak. Jogjakarta: Diva Press.; 2011.

11. Jeffrey S., Nevid SAR, \& Beverly Greene. Psikologi Abnormal. Ed. 9. Jakarta: Erlangga.; 2018.

12. Sainsbury MJ., Key to Psychiatry : Textbook for Student Third. Ed. 3. Australia: Griffin press limited.; 1984.

13. Stuart GW. Buku Saku: Keperawatan Jiwa. Buku Kedokteran : EGC.; 2006.

14. Santosh S., Roy D., Dutta, Kundu, P. S. Psychopathology, Cognitive Function, and Social Functioning of Patients with Schizophrenia. Academic Journal Article East Asian Archives of Psychiatry. Vol. 23.; 2013.

15. Wykes T, Huddy, V., Cellard, C., McGurk, S.R., Czobor, P. A Meta-Analysis of Cognitive Remediation for Schizophrenia: Methodology and Effect Sizes. American Journal Psychiatry. 168:47285.; 2011.

16. Anindya H. Efektifitas Senam Otak terhadap Fungsi Kognitif Penderita Skizofrenia di Komunitas Fakultas Kedokteran dan Ilmu Kesehatan. UMY: Universitas Muhammadiyah Yogyakarta.; 2015.

17. Weni Susilo Rini MNRH. Efektivitas Remediasi Kognitif terhadap Perbaikan Fungsi Kognitif pada Penderita Skizofrenia Rawat Inap di Rumah Sakit Jiwa Yogyakarta. Gadjah Mada Journal of Professional Psychology. Vol. 2:116-29.; 2016.

18. Amtonis I., Fata UH. Pengaruh Senam Otak terhadap Peningkatan Fungsi Kognitif. Jurnal Ners dan Kebidanan. 2014;1(2):087-92.; 2014.

19. Sangkanparan H. Otak Tengah Memang Dahsyat : Bukti-Bukti Dahsyatnya Otak Tengah 1ed. Jakarta Visimedia.; 2010.

20. Paul E., Dennison DED. Brain Gym : Buku Panduan Lengkap. Ed. 8. Gramedia.; 2005.

21. Purnama, Agus, Rina Afrina, and Nurul Ainu Shifa. "Stress and Relationship with Cognitive Disorders of Post-Stroke Patients." STRADA Jurnal Ilmiah Kesehatan 9.1 (2020): 1-5. 